\section{Bernard McCarthy O'Brien: The champ who was determined to excel}

orn on the auspicious Christmas day in 1924, Mr. Bernard O'Brien was a surgeon with a passion for excellence. Determined to train himself in microvascular free tissue transfer, before anyone in the world ever thought of it, he established a small microsurgery laboratory in St. Vincent's Hospital in Melbourne, Australia in 1976 and went on to train a generation of surgeons, plastic surgeons and orthopaedic surgeons, from every continent in the world, in the science and art of Microsurgery.

After gaining his medical qualifications and undertaking his residency years and surgical training at St. Vincent's Hospital, Melbourne and the Royal Melbourne Hospital, Bernard O'Brien worked as a Demonstrator in the University's Anatomy Department (1953) and in Clinical Surgery and Histopatology (1954), He received his Master of Surgery degree in 1955.

After his masters, he proceeded for further surgical training to England and was Nuffield Assistant in Plastic Surgery at Oxford University 1956-1957 under Mr. Pomfret Kilner. While in England and working in Odstock Hospital in Salisbury in 1957, Mr. O'Brien met Joan, who was the Sister second-in-charge of female plastic ward and married her. He sailed for New York, becoming one of the few Melbourne graduates of his era to gain formal surgical training in the US. For six months, he was Chief Resident to the Plastic and Reconstructive Service at Roosevelt Hospital. Following his overseas training, he

\begin{tabular}{|l|l|}
\hline \multicolumn{2}{|c|}{ Access this article online } \\
\hline Quick Response Code: & Website: \\
\hline & www.ijps.org \\
\hline & Dol: \\
\hline
\end{tabular}

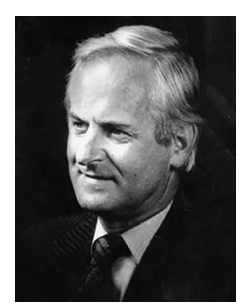

25.12 1924-14.08.1993

returned to Melbourne with dreams in his eyes of doing something new and unique.

Bernard O'Brien was always a leader and never a follower. Known since his university days as 'champ' because of his success in obtaining a University Blue for pole-vaulting despite an ankle injury, O'Brien showed typical tenacity in pursuing his goal of developing expertise in microsurgery. After his return to surgical practice in Melbourne, he lacked a hospital or academic appointment, but for several years in limbo undertook research on microsurgical techniques with the help of Professor Gerard Crock of the University's Ophthalmology Department. In 1964, he undertook studies on small blood vessels and nerves in a disused mortuary at St. Vincent's that had been converted into a primitive experimental operating theatre using a microscope loaned to him by Professor Crock at the Eye and Ear Hospital. Nothing could stop him once he made up his mind to achieve a goal, no matter how remote, how difficult and how punishing the path to success was. His wife Mrs. Joan O'Brien very rightly said - He "went ahead, no matter what and with a great sense of humour'.

Later in 1968, he was appointed Honorary Research Assistant in the University of Melbourne, Department of Surgery at St. Vincent's, Acting Assistant Plastic Surgeon at the hospital, and received a research grant of $\$ 2000$. The following year, he obtained a number of other grants, the largest being from the National Health and Medical Research Council to continue his research on experimental anastomosis of small blood vessels and nerves under magnification, thereby helping lay the foundations of clinical microsurgery. These grants, together with a fundraising 'Microsurgery Foundation' that he established and continually exhorted to greater efforts, provided the facilities and resources for the work of the Microsurgery Research Unit, which came into being in 1976. The Unit, later on became the Microsurgery Research Centre, which was something of a Mecca for overseas surgical fellows wanting to gain further training and the opportunity to undertake research on microsurgical techniques. The Microsurgery Research Centre developed a pre-eminent 
reputation and attracted plastic and orthopaedic surgeons from the US, UK, Europe, Asia and elsewhere and many of these researchers have returned to their home countries to become leaders in the field. More than 200 surgically trained researchers have completed fellowships since 1972. One of the walls of the Research Centre is adorned with the photographs of these fellows and one look at the wall tells you that all the stars in the galaxy of microsurgery, had at some time in their training phase, worked in this centre. In Prof. Wayne Morrison, Mr. Alan McLeod, Mr. Anthony Berger and Mr. David Jenner he had the best possible colleagues and together they formed a formidable training and teaching unit.

Mr. O'Brien wrote or co-wrote two classic text-books on microvascular reconstruction, Microvascular Reconstructive Surgery, published in 1977, and Reconstructive Microsurgery, co-authored with Professor Wayne Morrison, published in 1987.

He was active in community debate on public health measures, and was one of the groups of three influential doctors who appeared before a Victorian Government Committee on behalf of the Australian Medical Association to argue for the introduction of compulsory seat belt legislation.

He was also involved in professional surgical affairs, serving on the Council of the Royal Australasian College of Surgeons and as its Vice-President, and as President of the International Federation of Societies for Surgery of the Hand.

During his later years, troubled by vision problems, he became the planner and organiser for the Microsurgery Research Centre, rather than undertaking complex microsurgery himself. He was recognised as an honorary fellow by at least five international surgical colleges, including the American College of Surgeons, and was awarded many prestigious prizes. Bernard O'Brien died in harness while still serving as the Director of the Microsurgery Research Centre in 1993. Shortly before his death, the same year, he was awarded the highest honour of the Royal Australasian College of Surgeons, the Sir Hugh Devine Medal, in recognition of his surgical contribution.

When he died his good friend Dr. John Connell in his obituary wrote that he "possessed not only a rare talent, but also huge determination to excel in everything he attempted. His skill, his energy, application and drive lifted him like a champion above ordinary men. His friends say that the best way to get Bernard to do something was to tell him it could not be done. Miracles were to be done daily; the impossible achieved on a regular basis'.

After his demise, the Microsurgery Research Centre was renamed after him, and it became the Bernard O'Brien Institute of Microsurgery, carrying on with the rich tradition of clinical and experimental research. Keeping up with Mr. O'Brien's concepts of staying well ahead of time, in addition to pioneering techniques in reconstructive microsurgery, the institute today carries out internationally recognised scientific research in the fields of Tissue Engineering and Vascular Biology. With the universal adoption of microsurgery skills as a standard pre-requisite for all plastic surgeons, the need for clinical microsurgery training has diminished today and the Institute has evolved into basic science research, thus once again establishing itself as a leader in this field of research. It pioneers studies on angiogenesis, matrix biology, ischaemia-reperfusion injury, organogenesis, wound healing, nerve regeneration, cardiac muscle regeneration, inflammation, pain, the effects of trauma on tissue, and more recently, prostate cancer and diabetes. The Institute was among the first to realise that vascularisation of tissues, a concept fundamental to plastic surgery is a key to the successful translation of laboratory-based tissue engineering into humans and the Institute has developed a platform technology for vascularising tissue engineered products and organs, their fabrication and their transfer into patients.. This is a true tribute to Mr. Bernard O'Brien, and in his Institute and among his fellows the attitude of the 'champ' still lives on!

\section{Surajit Bhattacharya} Editor Indian Journal of Plastic Surgery, Fellow Microsurgery Research Centre, St. Vincent's Hospital, Melbourne, Australia E-mail: surajitbh@yahoo.co.in

How to cite this article: Bhattacharya S. Bernard McCarthy O'Brien: The champ who was determined to excel. Indian J Plast Surg 2014;47:282-3. 